\title{
Urban Mountain Waterscapes: The Transformation of Hydro-Social Relations in the Trans-Himalayan Town Leh, Ladakh, India
}

\author{
Judith Müller ${ }^{1,2, *}$, Juliane Dame ${ }^{1,2}$ and Marcus Nüsser ${ }^{1,2}$ (D) \\ 1 Heidelberg Center for the Environment (HCE), Heidelberg University, 69120 Heidelberg, Germany; \\ juliane.dame@uni-heidelberg.de (J.D.); marcus.nuesser@uni-heidelberg.de (M.N.) \\ 2 South Asia Institute (SAI), Heidelberg University, 69115 Heidelberg, Germany \\ * Correspondence: judith.mueller@uni-heidelberg.de
}

Received: 28 April 2020; Accepted: 11 June 2020; Published: 14 June 2020

\begin{abstract}
Socio-economic processes and climate change impact the socio-hydrology of many small towns in the Hindu Kush Himalaya (HKH), such as Leh in Ladakh. The rapidly urbanising town experienced a shift from agricultural livelihoods towards incomes mainly relying on the tourism sector. As results of this research show, the limited water resources essential to the everyday life of urban citizens have become increasingly important for the tourism sector and the urbanisation process. This study aims to understand the transformation of the urban mountain waterscape and the role of different actors involved. The waterscape approach frames hydro-social relations in a specific spatial context and additionally captures diverging hydromentalities within local actor constellations. Related discourses are materialised as water governance impacting the everyday life of urban citizens. A combination of quantitative, qualitative and participatory methods allows for a differentiated picture of current developments. Based on 312 household questionnaires, 96 semi-structured interviews, and a participatory photography workshop, this study provides evidence that urban restructuring induced by development imaginaries produces uneven water citizenships in Leh. Along with socio-economic shifts, the community-managed water regulation system is replaced by a technocratic scheme, centralising water supply and sanitation. While some of Leh's citizens benefit from urban restructurings, others are confronted with environmental and social costs, such as a deteriorating water quality and a further reduction in quantity.
\end{abstract}

Keywords: Ladakh; urbanisation; water governance; urban transition; waterscapes; water infrastructure; hydromentalities; water citizenships; hydro-social relations

\section{Introduction}

Small towns in the Hindu Kush Himalaya (HKH) increasingly face challenges caused by ecological, political, social, and economic transformations [1-5] that affect water quality, quantity, and adequate infrastructures. Most relevant triggers are rapid urbanisation processes [6,7]. Regardless of their size, small urban centres in the HKH have relevant functions for the surrounding rural areas and serve as hotspots for economic development, often accompanied by a decline in local agriculture and environmental degradation $[4,8,9]$. Besides urban restructuring and economic growth, which lead to changing water demands, climate change affects the sensitive mountain environments and the local hydrology [10].

For India, the unequal distribution of safe water supply and sanitation infrastructure in large urban agglomerations has been widely discussed [11-15], while less attention has been paid to small Himalayan towns. Contrasting widespread perceptions of geographical remoteness [16], the economic 
development of these mountain towns is embedded in national, transnational, and international relations. Furthermore, small towns in India often face a "triple challenge" [17] (p. 2833) as a result of neoliberal urban processes: they have limited financial and human resources to address growing socio-environmental problems caused by rapid capitalist development and (structural) disparities.

This study analyses challenges in the urban "mountain waterscape" [18] of the small town of Leh in Ladakh (Figure 1) which has 30,870 inhabitants, according to the latest census data from 2011 [19]. The Trans-Himalayan region is characterised by cold-arid conditions and strongly affected by climate change [20-22]. Water availability generally has a high intra-annual variability, while rural-to-urban migration and an increased influx of tourists put additional pressure on water resources. Groundwater demand has risen, whereas surface water use for agricultural irrigation has decreased over the last decades. Water infrastructures are generally exposed to natural hazards and climate change effects [23]. This set of socio-hydrological factors results in a challenge to sufficiently supply a growing number of permanent and non-permanent urban residents.

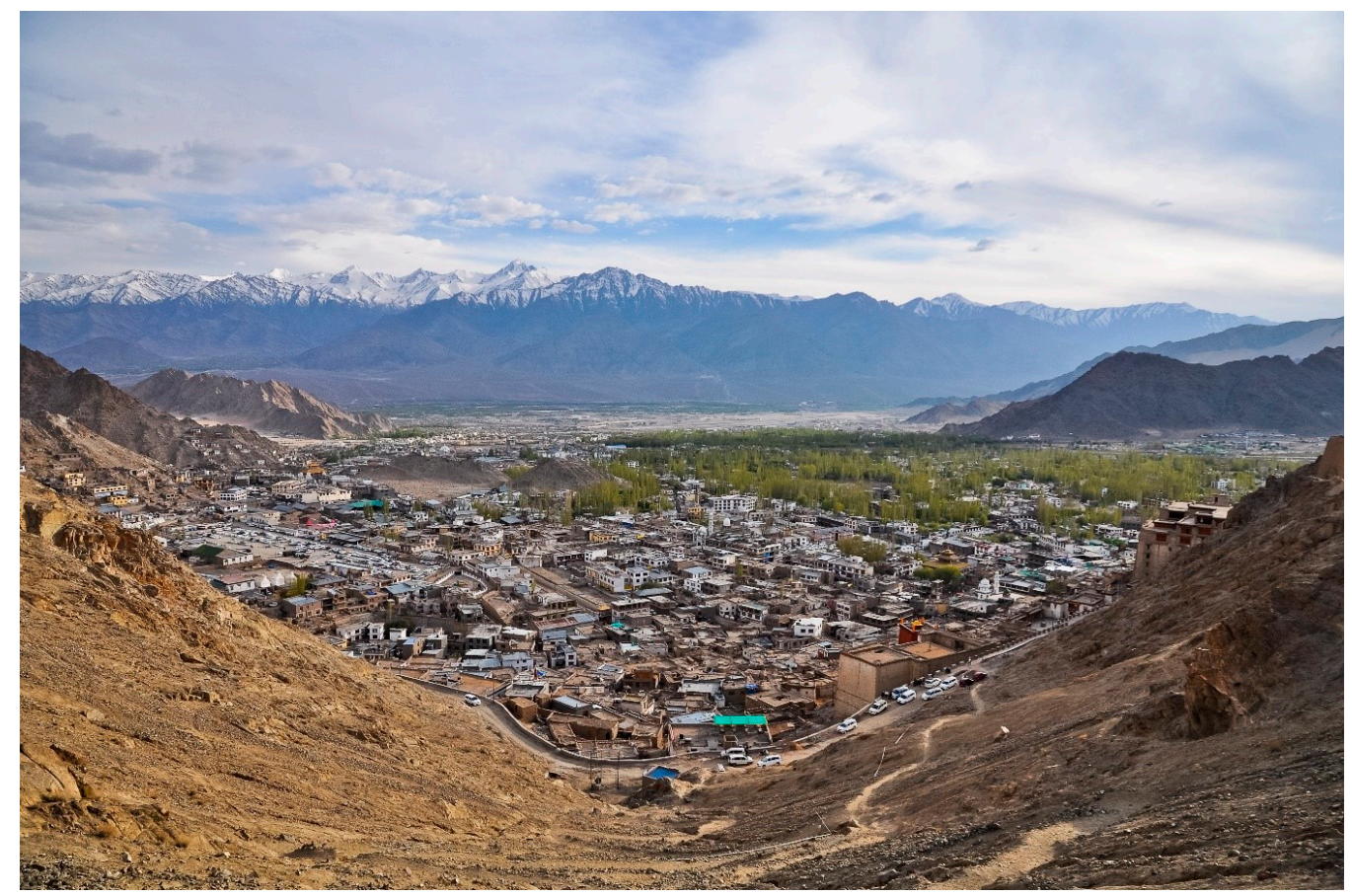

Figure 1. View of Leh town in southwest direction, with Old Town in the foreground (photo taken by Judith Müller, 2016).

One governance response is the implementation of a state-driven, centralised infrastructure scheme since 2014 to tackle Leh's rapid urban growth. The measures are financed by the "Urban Infrastructure Development Scheme for Small and Medium Towns" (UIDSSMT), a sub-scheme of the "Jawaharlal Nehru National Urban Renewal Mission" (JNNURM) of the Government of India. Besides the installation of a formalised water distribution network, it includes the construction of a new sewage system. The measures are part of a wider aspiration of the Indian state towards science-led, modern water management [11]. The urban renewal programme in Leh further encompasses waste management, road networks, and beautification of the bazaar area.

In addition to the dominant modernisation discourses, critical views question the suitability of solutions centralising water governance. Several NGOs and sections of the local community have discussed alternative pathways to sustainable urban water governance. Following up on the incentives of engaged research [24,25], one focus is to integrate civil society voices and concerns with negotiations on developments within the urban mountain waterscape. 
This study of current socio-economic and political processes of water use and infrastructures in Leh builds on a combination of different conceptual approaches: waterscapes [23-25] and hydromentalities [26,27] help to explain current urban water dynamics in Leh, which result in certain water citizenships [28]. The results from this case study assess the interests and concerns of different actor groups, encompassing the local government, NGOs, entrepreneurs in the tourism sector, and residents, and offer a base for further decision-making.

Three main questions guide the analysis. (1) How do current urban transformations impact water use and infrastructures? (2) Which hydromentalities shape water governance and how does it affect water citizenships? (3) To what degree is alternative, civil society knowledge on sustainable and equitable water management mobilised?

A description of the conceptual framework used to analyse the urban mountain waterscape follows this introduction. In the subsequent section, the methods employed for the study are outlined and the research area is sketched. Next comes an assessment of current challenges evolving in Leh's waterscape and then a demonstration of water governance approaches and underlying discursive strands. In the remainder of the paper, the findings and the ensuing creation of water citizenships are discussed.

\section{Conceptual Approach}

Water and its control play a pivotal role in urban growth and expansion, with water being a hybrid at the intersection of urban ecology and society [26]. Originating from the framework of urban political ecology, the waterscape approach understands urban water dynamics as manifested through flows, institutions, and imaginaries and, thus, focuses on spatial, material and discursive facets of hydro-social relations [26-28]. A "geographical 'situatedness' of these relations" [27] (p. 2) considers local peculiarities. Water infrastructures, understood as material-discursive hybrids located at the intersection between technology, politics, nature, and culture, are another key to the analysis of waterscapes. In Ladakh, the high mountain context plays an eminent role, which is why the concept is extended to "urban mountain waterscapes".

The hydromentalities concept is integrated into the urban mountain waterscapes framework (Figure 2), as it is relevant to understand how water is governed and power relationships are realised $[29,30]$. Based on Foucault's thoughts on governmentality, hydromentality investigates the power of mentalities, rationalities and resulting conducts that are embedded in so-called "regimes of truth" [31]. The emphasis is on the indirect power of dominant discourses beyond governmental power for influencing societies [32]. Hydromentalities are, thus, " . . specific governing techniques, such as responsibilisation and the 'conduct of conduct', that is the steering of people's behaviour around water" [33] (p. 7). Hydromentalities have a direct influence on everyday geographies of water use and socio-spatial practices by implementing hegemonic ontologies of water [34]. Hydromentalities, practices and relations shape the waterscape and the negotiations which arise at the intersection of the state and its citizens [35].

Citizenship is first and foremost perceived as a legal concept; however, it can also be understood in terms of everyday practices. Infrastructure plays a pivotal role in this understanding, as "notions of the state, and state power and authority, are shaped by specific interactions with differentiated municipal water and sanitation infrastructures, which in turn shape how citizenship is understood and narrated" [36] (p. 337). "Modern" water citizenship implies that the responsibilities for water management are centralised at the national scale, where the state provides social and communal water infrastructures, from which citizens benefit [37]. 


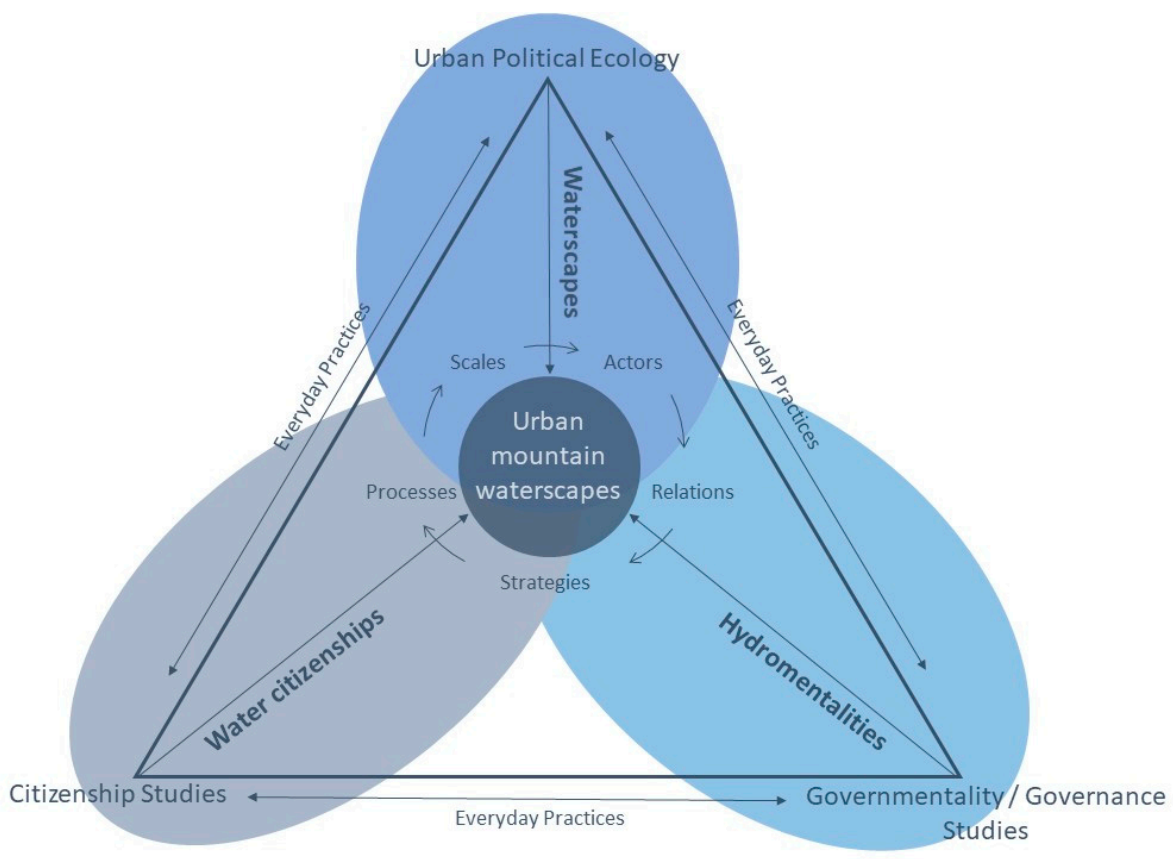

Figure 2. Conceptual framework (own draft).

\section{Methods}

The study combines quantitative, qualitative, and participatory social science approaches. The data were gathered during field campaigns between 2014 and 2018. The triangulation of qualitative and quantitative methodologies is employed to produce knowledge on different levels [38] and is particularly useful for multi-dimensional research in human geography focused on social change [39]. In total, 96 qualitative semi-structured and narrative interviews were conducted with officials of the district government (Ladakh Autonomous Hill Development Council-LAHDC), NGO members, hotel owners, farmers, teachers, journalists, and other residents. Interviews addressed urban development, agricultural practices, changes in water quantity and quality, tourism development, and perceptions of climate change. Furthermore, attention was paid to the strategies, reasoning, and perceptions around the current water infrastructure project. Household questionnaires $(n=312)$ were carried out in six out of 21 wards in Leh. These represent different socio-economic backgrounds, land use, water use, and settlement patterns. The primary unit of statistical sampling is the population of Leh, while the secondary units comprise the six focus wards. To avoid statistical discrimination due to varying populations of the secondary units and to account for an equal probability of selection for each sampling unit, "probability proportional to size sampling" was applied [40]. Every household where a respondent was present and willing to participate in the study was polled.

While the quantitative household survey was used to identify trends in urbanisation and water use, the qualitative data offered a deeper insight into the lived realities of the population as well as into the relationships and power asymmetries between various actors. The review of official town planning documents for water infrastructure enhanced the assessment of water governance in Leh. Additionally, a coliform bacteria test was performed in June 2016 to evaluate the suitability of the three main sources of potable water in Leh.

Another method employed was participatory photography to integrate local knowledge about urban water use and issues [41]. This provided insights into the opinions and perceptions of participants which were not otherwise visible through only verbal interviews. Maclean and Woodward [42] (p. 99f.) named two advantages of participatory photography:

1. "to enable people to record and reflect upon their community's strengths and concerns"

2. "to promote critical dialogue and collective knowledge production"

Participants were, in effect, made research collaborators rather than research subjects. 
This method was incorporated through a workshop organised in collaboration with the local NGO Ladakh Arts and Media Organisation (LAMO) in spring 2016. After an introductory workshop, ten participants between the ages of 16 and 45 were handed single-use cameras with which they were able to capture visual images of themes concerning water use and supply most relevant to them. After one week, the pictures were developed together with a local photographer and subsequently exhibited at the premises of LAMO. Finally, each participant was interviewed about the photographs she or he had taken, according to the method of photo elicitation [43].

\section{Study Area}

Leh is situated in a tributary valley of the upper Indus Basin on the south-facing slope of the Ladakh Range, sandwiched between the Greater Himalayan Range to the south and the Karakoram Range to the north. Due to rain-shadowing effects, Ladakh is a high-altitude desert which receives annual precipitation of about $100 \mathrm{~mm}$ [44]. Sufficient water supply is essential for agriculture in irrigated oases at altitudes from around 3200 to $3940 \mathrm{~m}$. The irrigation practices rely on a refined set of social structures and local institutions, sharing water between households through a rotational system [45]. The fluvio-glacial aquifer of Leh Valley depends almost exclusively on recharge by meltwater from the cryosphere [20] and risks a depletion through overuse in water-scarce periods prior to recharge by meltwater [46]. Seasonal scarcity in spring is exacerbated by high snowfall variability in winter, which is expected to decrease due to climate change [22,47,48]. Besides inter- and intra-annual variations in water availability, marked water fluctuations during the day are also characteristic within the region.

Water availability for sustaining livelihoods has historically differed across Leh: the Old Town historically used to be the residential neighbourhood. It was constructed outside the aquifer on non-arable land and consists of hillslopes with hard exposed, granitoid bedrock and the adjacent fluvial sediment. The precious fertile, irrigated area to the west with a high groundwater table and a surface water network with the main stream (Leh tokpo) and numerous channels was used for agriculture and was scattered with hamlets. Families used their houses in Old Town as winter residences and moved to their summer houses located within the irrigated area during the agricultural season [49].

As livelihoods have largely shifted from agricultural to monetised income activities, villagers from all over Ladakh have moved to the urban centre, aspiring for employment opportunities. Leh is of central importance to the whole district: since the latest Indian state reorganisation on 31 October 2019, Ladakh is a Union Territory without an elected legislative assembly. Instead, it will be administered by a Lieutenant Governor, who gets appointed by the central government. The regional government LAHDC, which was established in 1995, is based in Leh. It remains to be seen how effective the cooperation between these bodies will be in the future. Leh is a centre of transportation, healthcare, educational, commercial and administrative facilities. The administrative sector is an important employer and the army, exhibiting a high presence due to the border situation with Pakistan and China, offers a variety of work opportunities. Moreover, the army is a reason for the maintenance of road infrastructure [50-52]. After interstate confrontations with Pakistan in 1947, a military airport in Leh was built and since 1974, the airport has also served civic purposes and guarantees perennial access to the region, whereas roads are closed for approximately six months of the year due to the impassability of snow-covered passes.

Today, the local economy is primarily dependent on the tertiary sector, especially tourism, which represents a fast-growing industry offering manifold income opportunities. Since the opening of Ladakh to international visitors in 1974 and the continuous improvement of air connectivity, numbers have risen. A more than fourfold increase could be observed between 2010 and 2018, when 327,366 tourists (Figure 3), a number more than twice as large as the entire population of Ladakh, arrived at Leh, with a concentration on the summer months [53]. More than foreign tourism, domestic tourism has increased exponentially, as growing Indian middle classes can now afford to travel and it has become easier to reach Ladakh by air. 


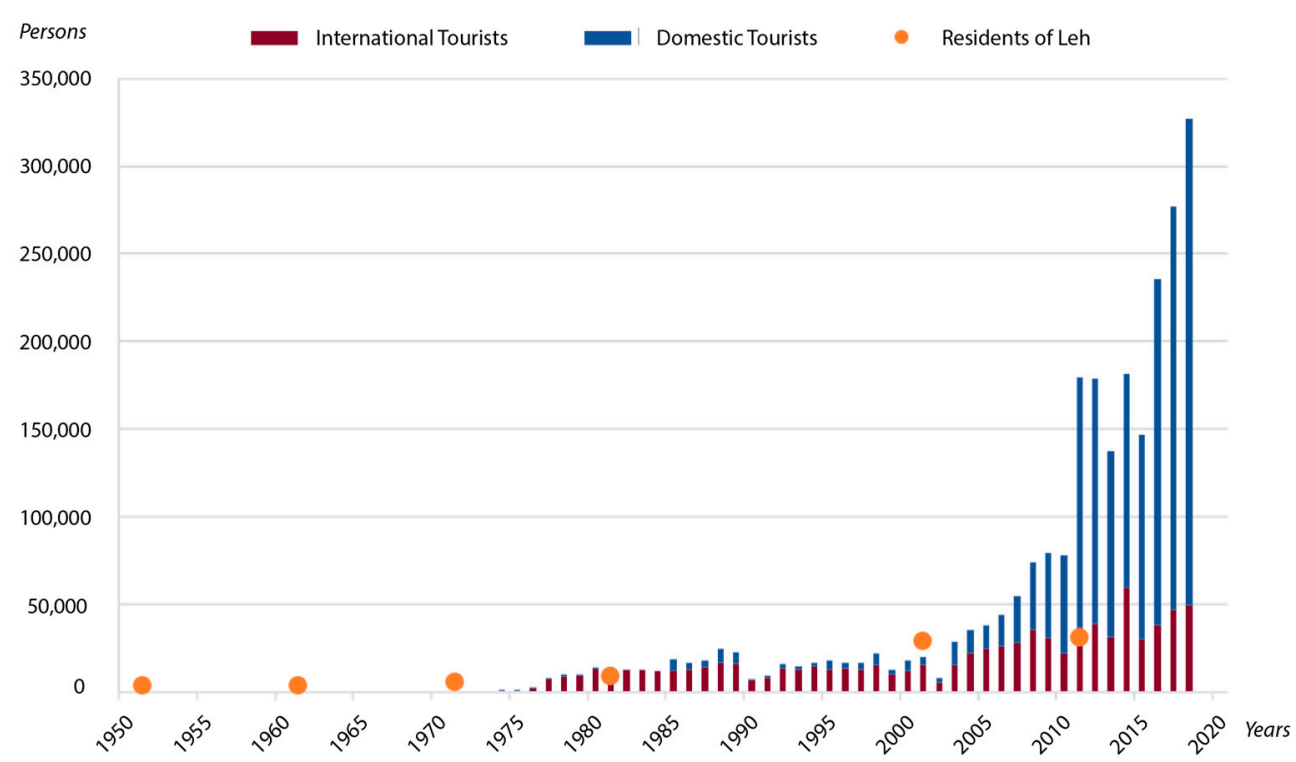

Figure 3. Tourist arrivals to Ladakh and population development in Leh (data: Census of India 2011 and Tourism Department, Leh 2019).

\section{Results}

\subsection{The Urbanisation of Water}

The traditional water sharing system based on diversion channels had for a long time been the main component of water use in Ladakh. In recent years, this has been to a large degree abandoned in Leh, as only a few farmers still practice agriculture here (Town hall meeting on water, 2018). As a consequence, the division of the town into cultivated and inhabited land has been eliminated and the former hamlets are integrated into the urbanised area: agricultural or barren fields mostly serve as building plots for two reasons. First, families are increasingly building private houses on their land as family structures change with more individual households (e.g., Interview, NGO member, 2014; Interview, Leh resident, 2015; Interview, Leh resident, 2018). Second, landowners get significantly higher returns from constructing touristic infrastructure on agricultural land than from farming, as explained by different members of civil society (e.g., Interview, NGO member, 2014; Interview, Leh historian, 2015; Interview, Leh resident, 2015). Widely replacing the traditional water sharing system based on surface water, groundwater has come to the fore of everyday water use (Figures 4 and 5).

Access to water resources in Leh varies according to the socio-economic structure and location of the residential areas. Out of the six surveyed wards, two are mainly inhabited by migrants from rural Ladakh (Nyimoling and Housing Colony). These wards are situated away from the aquifer of Leh Valley and therefore are provided less access to freshwater and hence no agricultural activities nor tourism businesses.

Three are former agricultural hamlets and were incorporated into the main town during the last decades (Skara, Chanspa, and Khakshal). Skara and Khakshal depict a combination of agricultural land use with little tourism infrastructure, whereas in Chanspa, agriculture has drastically decreased in favour of tourism. Old Town is the commercial centre and is distinct from other wards of Leh in terms of land use and socio-economic structure. There are guesthouses, shops, travel agencies, and restaurants that are integrated into the main commercial area. Many seasonal, non-Ladakhi migrants live in Old Town non-permanently. Families in Nyimoling and Housing Colony have an estimated average household income that is up to three times lower than families living in the agricultural wards (Figure 6). Migrants settle in the unfavourable areas of Leh, whereas land ownership and inheritance 
as well as access to sufficient water are historically and currently a wealth factor. These socio-economic inequalities are also reflected in water use and the distribution of water infrastructures.
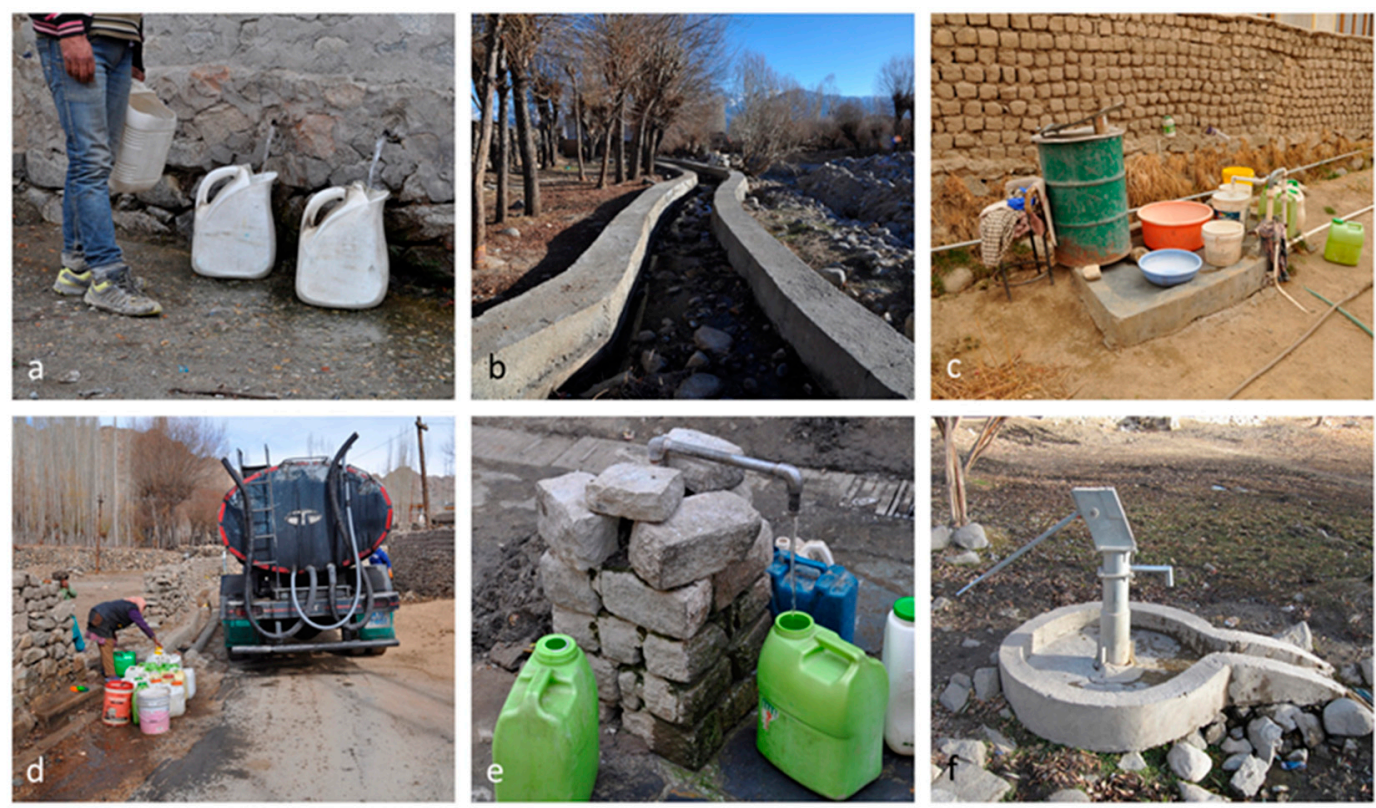

a Public drinking water source, $\mathbf{b}$ Water channel leading to a Zing, $\mathbf{c}$ Water access on private premises, $\mathrm{d}$ Water tanker delivery, e Pipelines of the UIDSSMT scheme, $\mathbf{f}$ Public water well

Figure 4. Water infrastructures commonly used for water supply (photos taken by Judith Müller, 2015-2018).
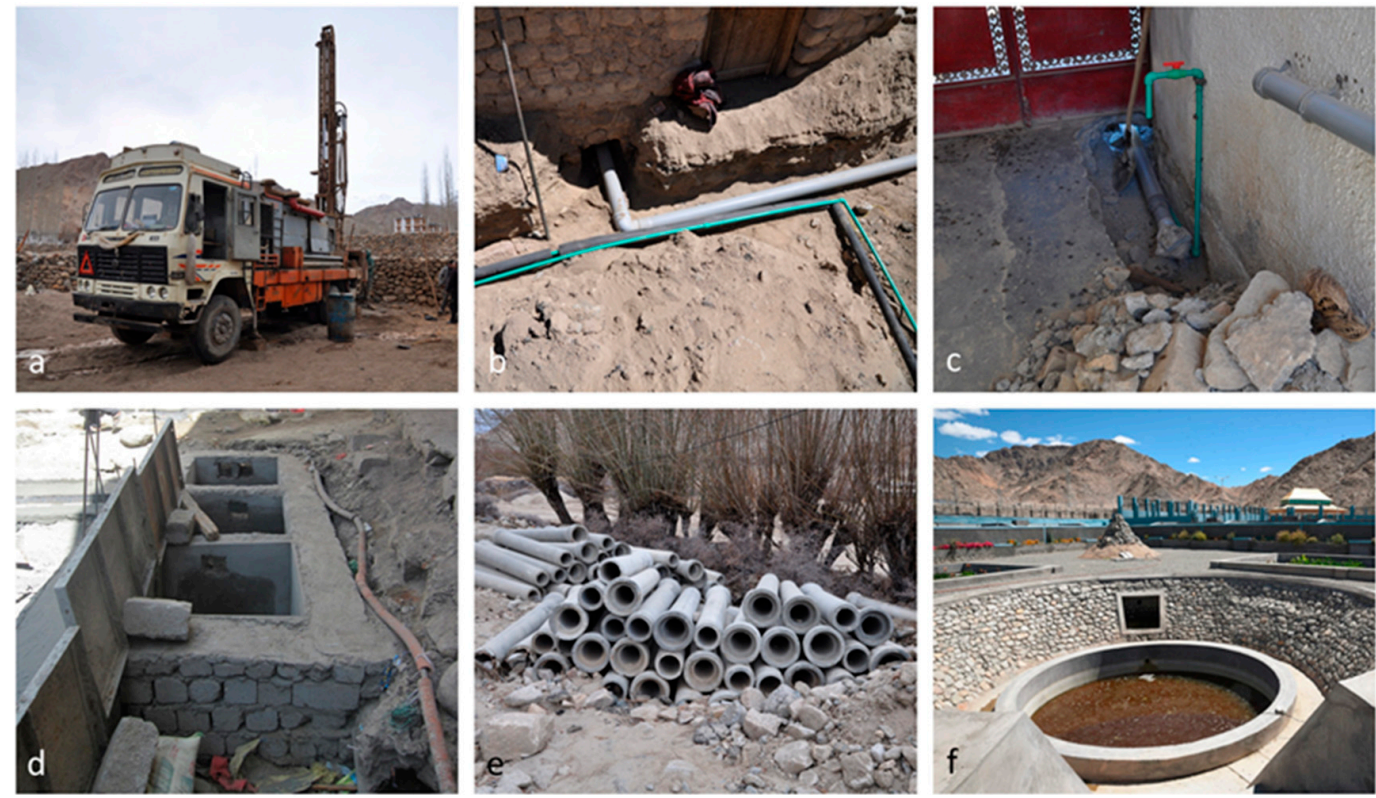

a Well driller, $\mathbf{b}$ Newly laid household water supply and sewage pipelines, $\mathbf{c}$ Water access on private premises, $\mathbf{d}$ Septic tank, e Stored pipelines for the UIDSSMT scheme, $\mathbf{f}$ Faecal Sludge Treatment Plant (FSTP)

Figure 5. Recently constructed water infrastructures in use (photos taken by Judith Müller, 2014-2018). 


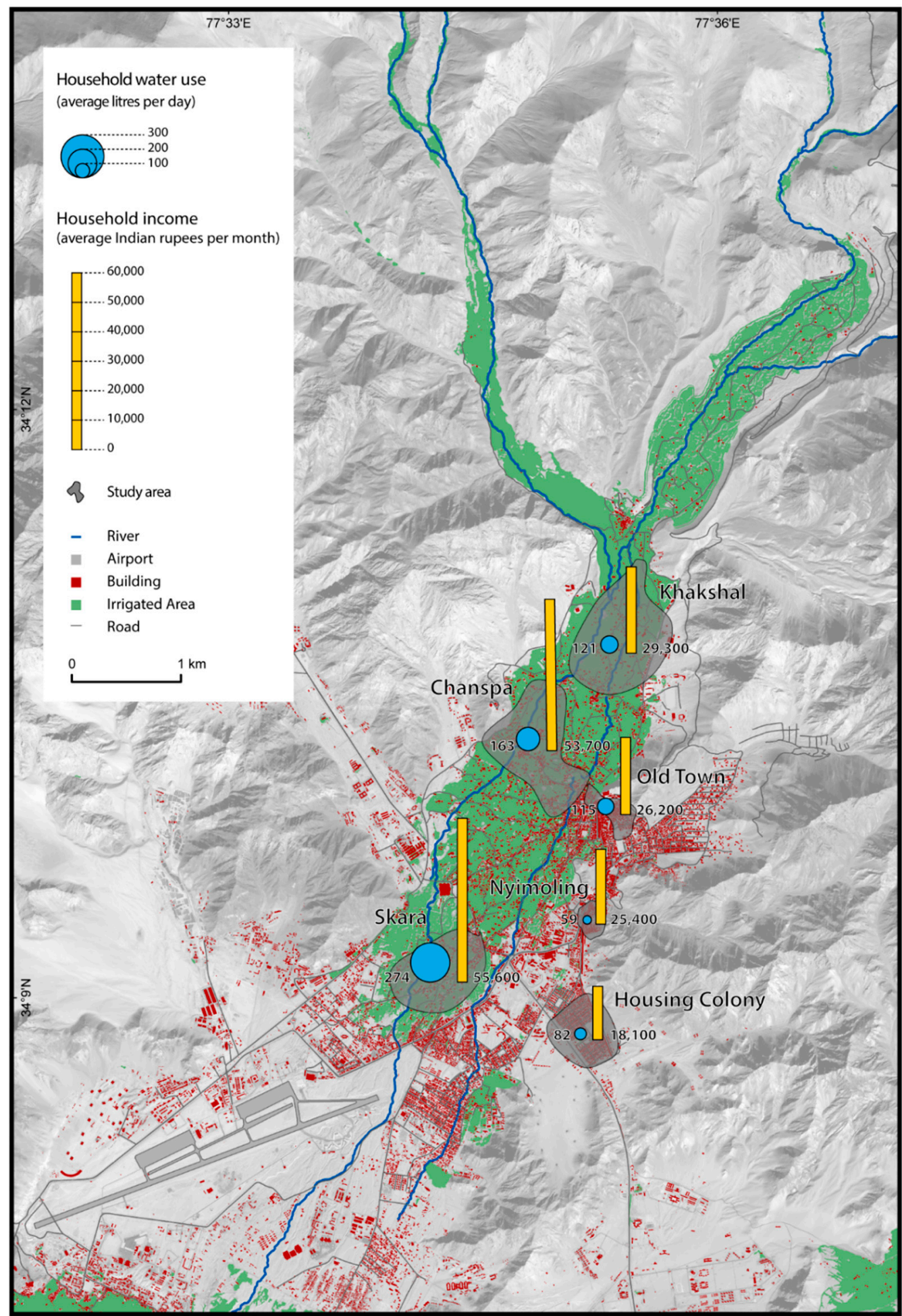

Base layer derived from Quickbird satellite image (7 Nov 2003). Mapping and update of urban infrastructure based on Pléiades data (22 Aug 2017) conducted by Susanne Schmidt. Thematic data on water use and income in focus wards mapped by Judith Müller. Study area is not equal to administrative units. ${ }^{*} 100$ Indian rupees are approx. 1.33 U.S. dollar.

Figure 6. Map of Leh with study areas, indicating income and water use.

While more than half of the urban population of Leh relies on public taps and pumps for every-day purposes such as fetching drinking and cleaning water, only $29.7 \%$ of respondents in all studied wards have access to a water supply line within their property $(\mathrm{n}=312)$. However, even the water supplied by pipes usually does not flow for more than two to three hours per day, which is insufficient to meet 
the demand of many users in the economic and private sectors. At the same time, water consumption is growing, as $49.3 \%$ of questionnaire respondents answered that they use more water than five years ago $(\mathrm{n}=304)$.

Regular water supply is particularly problematic in the economically weakest focus wards, namely Nyimoling and most parts of Old Town, which are predominantly not connected to the existing pipe system. The head of an NGO that works on restoring Old Town claimed that most likely, it will be difficult to connect households there in the future, as the subsoil is rocky and the preconditions for construction works are very challenging due to the narrow structure of the streets and houses (Interview, architect, 2016). At the same time, elite spaces serving touristic desires are being created: the main bazaar in Old Town has been reshaped by a beautification process to meet global and national consumption patterns and establish a water supply network, as part of the UIDSSMT scheme.

Due to more favourable aquifer conditions, groundwater access is easier across the traditional irrigated area. The three wealthiest wards of Leh with growing tourist infrastructures such as hotels and restaurants are located here. The high water demand of the tourism sector leads to a significant but not officially counted drilling of boreholes, as one hotel owner expresses: "There is not any alternative. We hear people saying, there have been so many boreholes coming up in Leh town, numbers are too much ... Definitely, it is a real fact that people are depending on the bore well. We are using it till such time when we have an alternative or you have to say no, stop the tourists, which is not possible". The wells are drilled in an unregulated manner by private companies, which require high initial investments, as stated by the owner of a borehole drilling company and a resident. Although the local government launched an appeal for owners of private wells to register with the LAHDC in September 2018, the drilling of wells has not yet been regulated.

In winter, most household supply pipes regularly freeze and only a few public taps can be used, as mentioned by several residents and a deputy of LAHDC's Public Health and Engineering Department (PHE). While public water tankers supply $23.5 \%$ of the total surveyed population of Leh, the inhabitants of the three non-agricultural wards do not receive such delivery services (interviews and household survey; $\mathrm{n}=312$ ). Self-assessments of private households with limited water access prove that they also generally consume less water, while guesthouses and hotels are characterised by higher consumption. The quantitative variability of water use depends on the location, the economic background, and resulting accessibility (Figure 6).

Private households, public buildings and touristic facilities predominantly use soak pits, often in close proximity to bore wells, which causes severe threats to water quality. The integration of soak pits into private households became necessary with a rising water use, especially due to a growing number of guesthouses and hotels emerging after Ladakh's opening to tourism. These produce far more wastewater than private households. In addition, private houses have also increasingly installed bathrooms and, consequently, rely on soak pits. Despite the official rule that hotels with 20 rooms or more must have their own treatment plant, only two hotels operated such plants in 2018, while the rest still uses soak pit solutions. The water quality testing conducted in June 2016 indicated bacterial contamination of one of the main spring sources for drinking water, frequently used by commercial water carriers who deliver water to restaurants, shops, or offices with carts. This source was officially shut down in summer 2017 due to contamination. Many residents of Leh expressed concerns of future drinking water quality: $18.4 \%$ of respondents already mentioned issues during surveys in 2015 and 2016, while NGOs and citizens reported declining quality of irrigation water due to polluted channels. The water quality of channels, springs, and groundwater thereby decreases from the upper to the lower town, due to the topography and density of the population.

\subsection{Development, Modernity and Urban Water Governance}

Two hydromentalities guide the current governance of Leh's waterscape: on the one hand, water is highly interconnected to imaginaries of modernity related to technological progress and economic development. In this context, tourism is regarded as the main strategy for economic growth, promoted 
by the local government and picked up by a large section of Leh's population. The Executive Councillor of Tourism stressed that Ladakh is blessed with high tourist numbers following the Bollywood movie "Three Idiots" (Interview, 2016). On the other hand, local and global climate change debates fuel widespread anxiety of a future decline in snow cover and glaciers, and thus freshwater, among the population, justifying external hydro-social interventions.

The previously fragmented water supply system, which relies to a large extent on springs and surface water, is framed as provincial and contradictory to modernity in planning documents of the UIDSSMT project [54]. Water supply under UIDSSMT is, thus, modernised by a Delhi-based company. Based on hydromentalities related to modernity and development, national and regional governments dominate current water governance in Leh. Instead of the formerly decentralised water governance, which relied on community-based management, the central scheme now favours a top-down water management approach. Against this background, water use is supposed to be formalised and disentangled as a response to a growing urban population and changing water use habits. The project addresses urban infrastructure considered to be inadequate to meet present requirements, including water supply, transport facilities, roads, sewerage and sanitation facilities [54]. As natural water springs are no longer sufficient to meet the demand of the water supply system, river water from the Indus is pumped to the upper part of Leh Valley by mechanically complex and energy-intensive technologies. From there, it is distributed via pipes, as explained by a PHE engineer.

With the new supply system, water is increasingly rendered invisible; on one hand to the underground sphere and on the other hand to private spaces. This has far-reaching implications. So far, water networks have been a core element of everyday culture in Ladakh, related to various religious and customary practices, such as inaugurations of springs and performances of rituals for water spirits, as a resident of Skara and NGO representative explains. In various interviews, respondents expressed the importance of water-related customs, like keeping water channels clean because of their sacredness. Moreover, fetching water at public springs has always been a social element in the everyday life of people. The introduction of a ubiquitous household supply grid leads to the increasing abandonment of traditional water customs.

The actor group of commercial water users raises concerns that the supply under the governmental water scheme will not be sufficient for economic aspirations. Alternative solutions for water supply are in use, such as private bore wells or deliveries by private tankers (Interview, hotel owner, 2018). Private households may face difficulties in their future water supply despite the official aim that "every house will be connected", expressed by the superintendent of the PHE Department. Politicians in charge also mentioned the inaccessibility and remote location of some buildings together with related technical issues. Until 2018, construction works of the UIDSSMT had not yet covered all wards of Leh.

Technical solutions and expert knowledge introduced by the government project encounter profound scepticism within the civil society. A representative of an NGO doubts that maintenance can be guaranteed: "What usually happens in India is, you build big infrastructure, the government pays you for it and then it goes down. There is no one to look after it". Members of two NGOs argue that the planned system is not adapted to local climatic and hydrological conditions, as well as cultural aspects [see also 2]. These critiques are shared by different interviewees, including local community representatives, entrepreneurs, citizens, and even local politicians.

The installation of a sewage system is another component of the UIDSSMT scheme to modernise water infrastructures that receives criticism. Construction work for the sewage treatment plant has not yet started due to judicial objections by the local community, forwarded by the two gobas (village heads) of the ward Agling (Interview, 2016), where the intended building site is located, and technical problems. Moreover, it is questionable whether a centralised sewage scheme is applicable in Leh, where nearly all households (92\%) use a traditional dry toilet (household survey; $\mathrm{n}=309$ ). At the same time, additional water closets are more and more common, as stated by an employee of the PHE Department and a resident (Interviews, 2015; 2018). In the surveyed wards, $28.5 \%$ own both toilet facilities and $7.3 \%$ exclusively use a water closet. It would be difficult to accustom the population to the exclusive 
use of water toilets, which is a prerequisite to ensure the functionality of the system, as the relatively large amount of $135 \mathrm{~L}$ per capita per day of water flow is needed [54]. An NGO member stressed that implementing a water-intensive sewage network is not sustainable in a semi-arid region where the local system of dry toilets has proven suitable over centuries (Interview, 2018). A local architect pointed out that it is ignored that many households in Leh have usage preferences that differ from those that the new system addresses (Interview, 2016). In the agricultural wards, dry toilets are still necessary for the production of manure. The establishment of a centralised sewage system introduces new patterns of hydro-social relations. The alleged odour from dry toilets is perceived as a nuisance for public life and therefore incongruous with the idea of a modern, sanitised city, as expressed by one non-local engineer implementing the water scheme (Interview, 2015).

Smaller guesthouses are mostly attached to private houses, i.e., currently use the same soak pit, and would, therefore, be covered by the centralised sewage system. In contrast, larger hotels are not targeted by the official scheme. To tackle the issue of growing amounts of faecal matter produced by the increasing number of hotels, a "Faecal Sludge Treatment Plant" (FSTP) was mounted in August 2017 through a public-private-partnership initiative. Currently, some army camps and hotels dispose of their sewage water to the FSTP. Yet the plant by far cannot meet the demand that exists in touristic wards like Chanspa, as an NGO member involved in the project pointed out. The hotel association of Leh perceives the situation as problematic and pledges fast troubleshooting.

Residents evaluate climate change-the second discursive strand-as a pressing problem. They expressed widespread anxiety about the consequences of climate change and an increase in water shortages in Ladakh: "In the future, we will face a lot of problems regarding water" (Interview, Leh resident, 2015) or: "As long as we have this glacier, we don't have any problem. But with the time, with this global warming, we fear that the glacier will decrease" (Interview, Leh resident, 2015). While some hold climate change responsible (e.g., Interview, Leh resident, 2018; Interview, NGO member, 2018), others point at the socio-economic processes in Ladakh, such as urbanisation, tourism, or army expansion: "There is going to be a water problem in the future. Because everyone is moving to Leh" (Interview, Leh resident, 2015). Not only scarcity is mentioned, but also a decrease in water quality is a problem for many, as an agriculturalist and NGO founder expresses: "Well, basically, all drinking water is contaminated, this is the problem" or "The groundwater in Leh is contaminated, for sure" (Interview, journalist and architect, 2016).

In this context, water shortages are mainly understood as a threat of climate change or population pressure that can be solved with technological solutions. One employee of the PHE Department states that future water shortages will be an "effect of global change" and that Leh will "rely on lifting water, but it is very cost-effective" (Interview, 2018). Not only government officials, but also parts of the local population believe in technological solutions for hydro-social challenges, as one resident expressed: "If you have a will, you can do anything. Because now, we are in the 21st century. We are in a century of machines. Not those days in the stone age" (Interview, 2016).

\subsection{Civil Society Perspectives on Water Governance}

The local magazine "Stawa" (October 2019) recently picked up the topic of a widespread scepticism regarding current economic and societal developments with its title: "Development in Ladakh-Is more tourism the answer?" This quote is a prime example of the growing resentment in parts of the population and NGOs towards current economic developments, the hydro-social consequences of which are unequally distributed among the population: while few people profit enormously from the touristic development in Ladakh, the vast majority gains to a limited extent but pays the price with a deteriorating urban environment, declining water quality and a growing waste management problem with rising traffic volumes, both related to a degradation of air quality. Parts of the population and civil organisations critically examine the commodification of water and the associated ideas of modernisation and development and create alternative approaches to human-water interactions. In this context, NGOs play an important role as mediators, offering spaces for negotiation and raising 
awareness. Various organisations have taken initiative in recent years to stimulate a public debate on environmental issues. They often receive financial support from foreign funding institutions for implementation of projects or collaboration with foreign scientists to create broad knowledge platforms. One example is the NGO LAMO that primarily works on education, cultural heritage, but also on environmental issues, such as the importance of water for the urban population. They usually choose an artistic approach for their projects. Another NGO is the Ladakh Ecological Development Group (LEDeG). LEDeG is one of the NGOs that has worked-among others-on sustainable development in Ladakh since the 1990s. Their focus is on water and agriculture. A third example is the Leh Nutrition Project, another long-established NGO in Ladakh that works on rural development, including the fields of agricultural sustainability and water resources. A long-term project receiving international recognition is the creation of ice reservoirs, commonly called "artificial glaciers".

Cooperation with the local NGO LAMO was essential for conducting this research, as it acted as a mediator between scientific, institutional, and community knowledge and aspirations. The participatory photography method enabled us to harness local knowledge and problem perceptions in order to initiate a dialogue about pathways towards sustainable water governance. The participants offered different approaches to current urban water challenges. Many pointed out problems already discussed beforehand, like degradation of water quality, a decline of water quantity due to overuse, and future anxiety concerning climate change. Repeatedly, participants compared the water situation from a few years ago with today and mentioned that water channels are more polluted and water availability is less today. One interviewed participant captured a scene of people queuing for water at a public stand post. He explained the setting: "Water is very precious, actually ... The officials release the water for one or one and a half hours. So, you need to store the water somewhere and bring many canisters. Everyone is waiting here and focussing on 'When is my turn'. This is why I found it interesting taking this picture" (Figure 7a). Another participant commented on a photo he took: "The people who are leading Ladakh, the Executive Councillors, they are talking big. Education and health should be the first priorities, I understand. But seeing this, I don't think health is going to be good. At least for the nearby people. Are they not able to see this?" (Figure 7b) and further he stated that in his home village, farmers do not have enough water for irrigation due to climate change: "Nowadays it is very difficult. Everyone is competing for water".
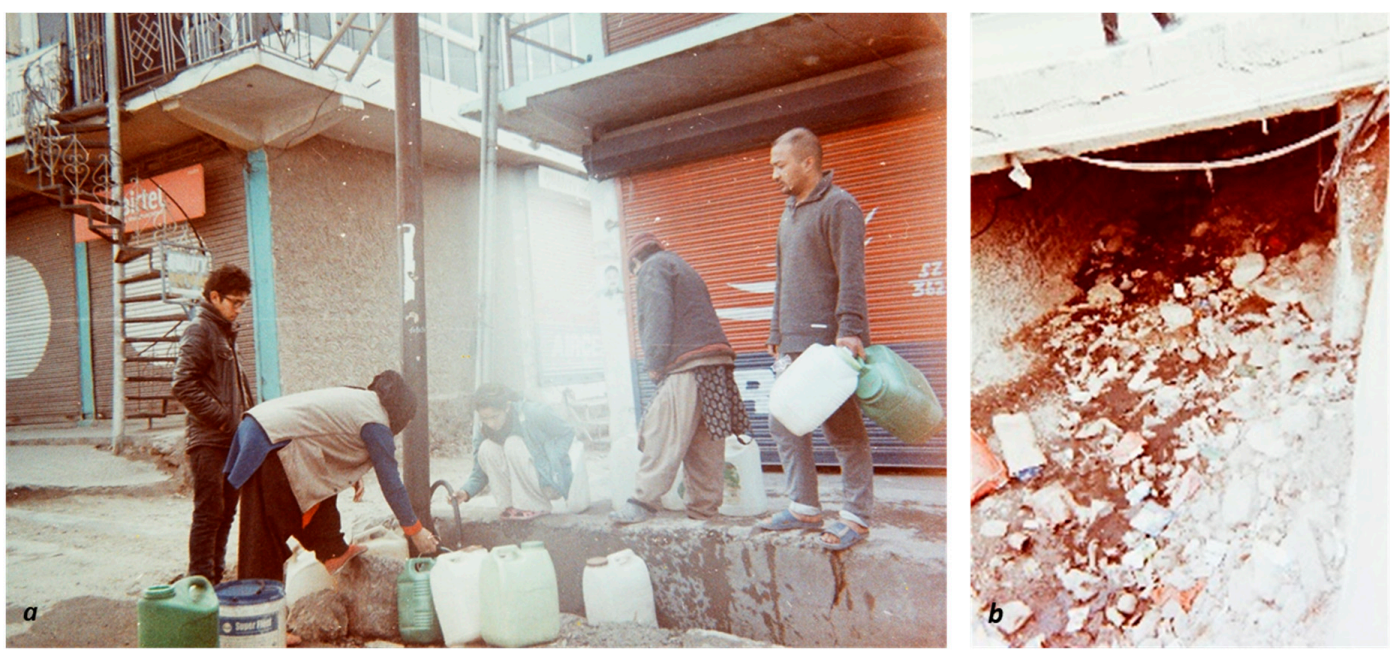

a Photo of residents waiting for their turn to fetch water (photo taken by participatory photography participant no. 10), b Polluted water channel (photo taken by participatory photography participant no. 9)

Figure 7. Photographs taken during the participatory photography workshop in 2016.

Moreover, the residents also mentioned spiritual and religious aspects of water and highlighted the deeply embedded cultural relevance of water in Ladakh. The interpretation of visual and verbal empirical material showed that water plays a fundamental role in the everyday life of participants 
and they are conscious of the physical limitations implied by the local setting. Yet, many also pointed out the shortcomings of current water governance, economic pressures on water resources, future anxieties, and spatial disparities within the local waterscape.

LAMO continued the public debate on water through different formats of co-learning and engaged artistic formats. Following the participatory photography workshop, LAMO organised an ascent to one of the important glaciers supplying water to Leh to document its size and decline. This expedition was led by an elderly livestock herder who had known the glacier since her childhood. This awareness-raising activity was published in the magazine of the NGO later and rendered the threat of climate change in Leh as more tangible.

Another recent initiative by the local NGO LEDeG is called "Liveable Leh" and aims to improve governance for sustainable town development and urban resilience to climate change by cooperating with the local government. During a town hall meeting in 2018, this initiative was presented after deliberations between different civil society organisations, experts, and the local government to create a space for exchange over water issues in Leh. This gave a voice to the local aspirations for a sustainable future of the town which could be expressed here. These interactions reiterated the urgency to create sustainable development to deal with scarcity that is likely to become even more pronounced in the future. Based on a collaboration with scientists from TU Munich (Germany) [55], LEDeG also proposed an alternative to LAHDC, arguing for the establishment of a partially decentralised wastewater recycling system. This proposal has not been implemented by the local government because of the already launched UIDSSMT project.

Generally, local NGOs try to influence Ladakhi politics where possible. One example of collaboration between the local government and NGOs is the formulation of the "Ladakh Vision 2025" document. It was drafted in 2005 by a committee comprising actors from the LAHDC, NGOs, and local societal and political elite in Ladakh as a base for development in the region. It emphasises the need for urban change: "To provide the growing population of Leh town with modern civic amenities, while focusing on restricting the ever-increasing numbers dependent on it (especially by discouraging the rural-urban migration pattern), and also addressing its ecological and environment related concerns" [56] (p. 31).

However, it is questionable how initiatives by NGOs are included in everyday politics besides acknowledging and integrating them into plans for sustainable development. In the context of the newly granted UT status and resulting political power shifts, the future impact of NGOs on local politics and potential for collaboration between governmental and non-governmental actors remain to be seen.

\section{Discussion: Hydromentalities and the Production of Uneven Water Citizenships}

The assessment of current urban transformations in water use and infrastructures shows a fragmented waterscape in Leh. Stakeholders on various scales are led by distinct hydromentalities in their everyday water use and their adaption to upcoming challenges for water governance. The most dominant regime of water governance traverses from the national to the local scale where it influences the everyday water use of households: The governmental UIDSSMT scheme is supposed to regulate water use and to enhance economic growth through infrastructure modernisation and development. Fragmented and informal water supply, in contrast, is regarded as underdeveloped and opposed to modernity [57]. The relatively new phenomenon to integrate bathrooms into private houses in Ladakh leads to a rise in water consumption and a growing aversion towards human excrement. They can now be flushed away into a hidden network that "mak[es] the visible invisible" [58] (p. 49). Water consumption becomes a private issue and is subject to a subtle mode of social discipline [59] (p. 367). Meanwhile, water channels are used as an open drain. The overuse and quality decline of water resources in combination with a lack of manure through the reduced use of dry toilets leads to a disruption of a formerly sustainable agricultural cycle. Traditional knowledge gets lost and new external dependencies endangering future food and water security are created. 
Being a symbol of urban modernity [2,11], the introduced technology is to a large extent inappropriate in the semi-arid high mountain region. The UIDSSMT mission does not consider local particularities, such as the specific hydrology and geomorphology of the area as well as socio-cultural or religious aspects. Similar to other towns of the $\mathrm{HKH}$, the functionality of these infrastructures requires reliable energy supply and technological knowledge. Ongoing investments, abilities and capacities of the local governments in maintenance and operations are needed [4].

For the local population, water is, on the one hand, a basic prerequisite for economic success in the tourism sector. On the other hand, many citizens perceive water as a scarce resource and are concerned about climate change's impacts in the future. These fears can be considered and utilised by a government, if hydromentalities of scarcity can govern the resource use of a society [30]. Whereas pronounced seasonality is a characteristic factor of the regional hydrology, scarcity is now also a regime to evaluate water as an economic good and frame it as a problem that can be solved with state-led technocratic solutions.

Water governance and thus responsibilities to ensure sufficient quantity and quality have moved from the community scale to the local and national government in the last decades, leading to shifting water citizenships. Meanwhile, gaps in the grid are filled through private initiatives, for example by drilling bore wells. These relocations affect public and private life and can be understood as a development towards "modern citizenship" [37] (p. 84), intertwined with the globalisation of industrial capitalism, liberalism and modernity. In the frame of neoliberal developments, agricultural activities decrease and natural resources, such as water, deteriorate. The perceptions of the local population are congruent with the results of Schwaller [60], who tested the groundwater extracted by private bore wells. He found widespread water pollution with nitrate, Escherichia coli, and Enterococci bacteria, due to the high rates of inadequately disposed wastewater of hotels and guesthouses.

Shortages in water quantity and a degradation of water quality burden especially those with a weaker economic background. They have fewer possibilities to fill gaps in the governmental water grid and access clean water on an everyday basis. Hence, inequalities are provoked. Moreover, as Ternes [61] (p. 366) illustrates, "access to natural resources plays an important role in how the boundaries of citizenship are defined". Yet, spatial inequality of water citizenships is not the only issue. Additionally, scalar inequality is created through a social stratification from the international to the local scale during the main tourist season in summer. On the two extreme ends, national and international, wealthy tourists come to Leh and migrants from other parts of India or Nepal arrive as labourers.

Seeing the economic revenue of domestic tourism, Prime Minister Modhi urged Indians to visit touristic sites in their own country [62]. Apart from strengthening the economy, another motivation is presumably to strengthen the identification with remote parts of India, such as Ladakh. Infrastructure projects of the Indian state serve to enhance its influence in the culturally different, mountainous regions of the country [63]. Especially for places with national significance, like the contested border region, domestic tourism can play an important role in national integration [64]. Consequently, urbanites coming to Ladakh could render the town as a recreational "neighbourhood of the metropolitan areas" [65] (p. 155) and have an impact on transformations of the urban mountain waterscape. Following far-reaching political changes due to the administrative reorganisation making Ladakh a Union Territory, there are expectations that even more visitors might come to Ladakh in the coming years. A new administrative set-up was caused by the abrogation of Article 370, granting special status to Jammu and Kashmir until October 2019. Large scale investments can now be undertaken by people who do not originate from Ladakh. However, the details are vague, given current uncertainties, for example the ongoing political conflict in the wider Kashmir region or sudden crises such as the COVID-19 pandemic in 2020.

Site-specific factors impact the challenging condition of the hydro-social system. Although the volume of the groundwater body is so far unknown, it can be assumed that overuse of groundwater combined with uncertain dynamics of climate change affected cryospheric resources, essential for 
recharge, will cause limits to urban and economic growth. Groundwater recharge will presumably not be sufficient to meet current demands in the future. Additionally, climate change in the HKH region is expected to lead to an increased occurrence of droughts and floods [66]. Ladakh faced two major floods in the years 2010 and 2015, with severe impacts on the urbanised area and the water supply system. Pumping up water from the Indus River for future water supply might bring new risks due to damaged infrastructures and power outages during extreme weather events.

\section{Conclusions}

The case study is illustrative for similar challenges of rapid urban development in the face of global change that small towns in the HKH region face. Far-reaching inequalities are the outcome of hydro-social transformations, as there are always those who are deprived by and those who benefit from such processes. The mountain setting with steep terrain, limited resources and frequent natural hazards aggravates challenges for urban water governance, as it comes along with sensitivities towards climate change and environmental degradation.

The results from this study show that in the course of urbanisation in Leh, water resources have deteriorated, and a well-established system of water sharing has been abandoned. The creation of new non-agricultural wards in the town has far-reaching implications for the governance of limited water resources.

The urban mountain waterscape of Leh is reconfigured by the interests of different actor groups on the national, regional, local, and household scale and their specific strategies to cope with water issues. Hydromentalities of development, modernity, and scarcity related to climate change prevail in parts of the population and the government and legitimise state-led, technocratic forms of water governance. This governance tends to exacerbate unequal water citizenships. Those who live in disadvantaged wards due to their migration history are also the ones who are more likely to suffer from deterioration and limitation of water resources. In addition, the objectives of the infrastructure centralisation project have not been achieved yet. Alternative approaches for sustainable and equitable water development in the future are discussed by the civil society. Different non-governmental actors collaboratively develop approaches for sustainable (water) development. While NGOs in Ladakh take a strong role in public debates and are often heard by the government, not all initiatives are translated into action. Engaged, participatory research praxis revealed a wish from the civil society for further integration of local knowledge and concerns into town planning and sustainable water governance.

An approach that builds upon exchange between different actors such as the town hall meeting in 2018 is a positive onset to integrate actors on various scales and with diverging interests. However, there remains scope for more intense collaboration. Long-established modes of water governance at the communal scale should be discussed in light of the latest research findings on urban water sustainability.

Author Contributions: Conceptualization, J.M., J.D. and M.N.; methodology, J.M.; formal analysis, J.M.; investigation J.M., J.D. and M.N., writing—original draft preparation, J.M., writing-review and editing, J.D. and M.N., visualization, J.M., supervision, J.D. and M.N., project administration, J.D.; funding acquisition, J.D. All authors have read and agreed to the published version of the manuscript.

Funding: This study was funded by the Heidelberg Center for the Environment (HCE) at Heidelberg University as part of the Junior Research Group “Environment and Health in Arid Regions" (D.801000/12.032 ZUK 49/2 5.3.1 HCE, grant holder: Juliane Dame). Judith Müller received additional funding from the Graduate Academy of Heidelberg University. Marcus Nüsser received travel support from Heidelberg University.

Acknowledgments: We would like to express our gratitude to all interview partners working with NGOs and government departments, household members in the study wards, and field assistants in Leh, Ladakh. Without their knowledge and experience this work would not have been possible. Susanne Schmidt, Dagmar Brombierstäudl and Maike Petersen (all Heidelberg University) helped with Figure 6. Anna Sophie Dame and Medha Chaturvedi (Heidelberg University) helped editing the final manuscript. We would like to thank the two anonymous reviewers and the editors for their valuable comments on an earlier version of the manuscript.

Conflicts of Interest: The authors declare no conflict of interest. 


\section{References}

1. Mohanty, S.; Bhagat, R.B. Spatial Pattern of Urbanisation and Urban Growth in Western Himalayan Region in India. In Population, Health and Development: Perspectives on Uttarakhand; Sekher, T.V., Singh, A., Parasuraman, S., Eds.; Academic Foundation: New Delhi, India, 2013; pp. 413-434, ISBN 978-8171889464.

2. Gondhalekar, D.; Nussbaum, S.; Akhtar, A.; Kebschull, J. Planning Under Uncertainty: Climate Change, Water Scarcity and Health Issues in Leh Town, Ladakh, India. In Sustainable Water Use and Management; Leal Filho, W., Sümer, V., Eds.; Springer International Publishing: Cham, Switzerland, 2015; pp. 293-312, ISBN 978-3-319-12393-6.

3. McDuie-Ra, D.; Chettri, M. Himalayan Boom Town: Rural-Urban Transformations in Namchi, Sikkim. Dev. Chang. 2018, 49, 1471-1494. [CrossRef]

4. Kovács, E.K.; Ojha, H.; Neupane, K.R.; Niven, T.; Agarwal, C.; Chauhan, D.; Dahal, N.; Devkota, K.; Guleria, V.; Joshi, T.; et al. A Political Ecology of Water and Small-town Urbanisation across the Lower Himalayas. Geoforum 2019. [CrossRef]

5. Prakash, A.; Molden, D. Editorial: Mapping Challenges for Adaptive Water Management in Himalayan Towns. Water Policy 2020, 22, 1-8. [CrossRef]

6. Dame, J.; Schmidt, S.; Müller, J.; Nüsser, M. Urbanisation and Socio-ecological Challenges in High Mountain Towns: Insights from Leh (Ladakh), India. Landsc. Urban Plan. 2019, 189, 189-199. [CrossRef]

7. Wang, Y.; Wu, N.; Kunze, C.; Long, R.; Perlik, M. Drivers of Change to Mountain Sustainability in the Hindu Kush Himalaya. In The Hindu Kush Himalaya Assessment: Mountains, Climate Change, Sustainability and People; Wester, P., Mishra, A., Mukherji, A., Shrestha, A.B., Eds.; Springer: Cham, Germany, 2019; pp. 17-56, ISBN 978-3-319-92287-4.

8. Geneletti, D.; Dawa, D. Environmental Impact Assessment of Mountain Tourism in Developing Regions: A Study in Ladakh, Indian Himalaya. Environ. Impact Assess. Rev. 2009, 29, 229-242. [CrossRef]

9. Pandit, M.K.; Manish, K.; Koh, L.P. Dancing on the Roof of the World: Ecological Transformation of the Himalayan Landscape. BioScience 2014, 64, 980-992. [CrossRef]

10. Krishnan, R.; Shrestha, A.B.; Ren, G.; Rajbhandari, R.; Saeed, S.; Sanjay, J.; Syed, M.A.; Vellore, R.; Xu, Y.; You, Q.; et al. Unravelling Climate Change in the Hindu Kush Himalaya: Rapid Warming in the Mountains and Increasing Extremes. In The Hindu Kush Himalaya Assessment: Mountains, Climate Change, Sustainability and People; Wester, P., Mishra, A., Mukherji, A., Shrestha, A.B., Eds.; Springer International Publishing: Cham, Germany, 2019; pp. 57-97, ISBN 978-3-319-92288-1.

11. Gandy, M. Landscapes of Disaster: Water, Modernity, and Urban Fragmentation in Mumbai. Environ. Plan. A 2008, 40, 108-130. [CrossRef]

12. McFarlane, C. Governing the Contaminated City: Infrastructure and Sanitation in Colonial and Post-Colonial Bombay. Int. J. Urban Reg. Res. 2008, 32, 415-435. [CrossRef]

13. Truelove, Y. (Re-)Conceptualizing Water Inequality in Delhi, India Through a Feminist Political Ecology Framework. Geoforum 2011, 42, 143-152. [CrossRef]

14. Graham, S.; Desai, R.; McFarlane, C. Water Wars in Mumbai. Public Cult. 2013, 25, 115-141. [CrossRef]

15. Anand, N. Hydraulic City. Water and the Infrastructures of Citizenship in Mumbai; Duke University Press: Durham, UK, 2017; ISBN 9780822362548.

16. Aggarwal, R. Beyond Lines of Control. Performance and Politics on the Disputed Borders of Ladakh, India; Duke University Press: Durham, UK, 2004; ISBN 978-0-8223-3414-9.

17. Véron, R. Small Cities, Neoliberal Governance and Sustainable Development in the Global South: A Conceptual Framework and Research Agenda. Sustainability 2010, 2, 2833-2848. [CrossRef]

18. Nüsser, M. Socio-hydrology: A New Perspective on Mountain Waterscapes at the Nexus of Natural and Social Processes. Mt. Res. Dev. 2017, 37, 518-520. [CrossRef]

19. Census of India. District Census Handbook Leh (Ladakh). Village and Town Wise Primary Census Abstract (PCA). Jammu and Kashmir, Series-02, Part XII-B. Available online: http://www.censusindia.gov.in/ 2011census/dchb/0103_PART_B_DCHB_LEH\%20(LADAKH).pdf (accessed on 11 December 2018).

20. Schmidt, S.; Nüsser, M. Changes of High Altitude Glaciers in the Trans-Himalaya of Ladakh over the Past Five Decades (1969-2016). Geosciences 2017, 7, 27. [CrossRef] 
21. Beck, H.E.; Zimmermann, N.E.; McVicar, T.R.; Vergopolan, N.; Berg, A.; Wood, E.F. Present and Future Köppen-Geiger Climate Classification Maps at 1-km Resolution. Sci. Data 2018, 5, 1-12. [CrossRef] [PubMed]

22. Chevuturi, A.; Dimri, A.P.; Thayyen, R. Climate Change over Leh (Ladakh), India. Theor. Appl. Climatol. 2018, 131, 531-545. [CrossRef]

23. Ziegler, A.D.; Cantarero, S.I.; Wasson, R.J.; Srivastava, P.; Spalzin, S.; Chow, W.T.L.; Gillen, J. A Clear and Present Danger: Ladakh's Increasing Vulnerability to Flash Floods and Debris Flows. Hydrol. Process. 2016, 30, 4214-4223. [CrossRef]

24. Community Resilience, Universities and Engaged Research for Today's World; Madsen, W.; Costigan, L.; McNicol, S. (Eds.) Palgrave Macmillan: London, UK, 2015; ISBN 9781137481054.

25. van Zandt, S.; Masterson, J.; Newman, G.; Meyer, M. (Eds.) Engaged Research for Community Resilience to Climate Change; Elsevier: Amsterdam, The Netherlands, 2020; ISBN 978-0-12-815575-2.

26. Swyngedouw, E. Social Power and the Urbanization of Water. Flows of Power; Oxford University Press: Oxford, UK; New York, NY, USA, 2004; ISBN 0-19-823391-4.

27. Karpouzoglou, T.; Vij, S. Waterscape: A Perspective for Understanding the Contested Geography of Water. Wiley Interdiscip. Rev. Water 2017, 4, e1210. [CrossRef]

28. Budds, J.; Hinojosa-Valencia, L. Restructuring and Rescaling Water Governance in Mining Contexts: The Co-production of Waterscapes in Peru. Water Altern. 2012, 5, 119-137.

29. Lankford, B. Infrastructure Hydromentalities; Water Sharing, Water Control and Water (In)Security. In Water Security; Lankford, B., Bakker, K., Zeitoun, M., Conway, D., Eds.; Taylor \& Francis Ltd.: London, UK, 2013; pp. 256-272, ISBN 9780415534710.

30. Hellberg, S. The Biopolitics of Water. Governance, Scarcity and Populations; Routledge: Abingdon, UK; New York, NY, USA, 2018; ISBN 978-1-138-74075-4.

31. Foucault, M. Discipline and Punish. The Birth of the Prison; Recording for the Blind \& Dyslexic: Princeton, NJ, USA, 2007; ISBN 0-679-75255-2.

32. Huxley, M. Geographies of Governmentality. In Space, Knowledge and Power: Foucault and Geography; Crampton, J.W., Elden, S., Eds.; Ashgate: Aldershot, UK; Burlington, NJ, USA, 2007; pp. 185-204, ISBN 978-0-7546-4655-6.

33. Hellberg, S. Scarcity as a Means of Governing: Challenging Neoliberal Hydromentality in the Context of the South African Drought. Environ. Plan. E Nat. Space 2019, 2514848619853551. [CrossRef]

34. Mele, C. The Materiality of Urban Discourse: Rational Planning in the Restructuring of the Early Twentieth-Century Ghetto. Urban Aff. Rev. 2000, 35, 628-648. [CrossRef]

35. Yates, J.S.; Harris, L.M.; Wilson, N.J. Multiple Ontologies of Water: Politics, Conflict and Implications for Governance. Environ. Plan. D Soc. Space 2017, 35, 797-815. [CrossRef]

36. Rodina, L.; Harris, L.M. Water Services, Lived Citizenship, and Notions of the State in Marginalised Urban Spaces: The Case of Khayelitsha, South Africa. Water Altern. 2016, 9, 336-355.

37. Gregory, D.; Johnston, R.; Pratt, G.; Watts, M.; Whatmore, S.J. The Dictionary of Human Geography, 5th ed.; Wiley-Blackwell: Malden, MA, USA, 2009; ISBN 978-1-4051-3287-9.

38. Denzin, N.K. Sociological methods. a sourcebook; Butterworth: London, UK, 1970; ISBN 0408701250.

39. Kotus, J.; Rzeszewski, M. Methodological Triangulation In Movement Pattern Research. Quaest. Geogr. 2015, 34, 25-37. [CrossRef]

40. Lavrakas, P. Probability Proportional to Size (PPS) Sampling. In Encyclopedia of Survey Research Methods; Lavrakas, P., Ed.; Sage Publications, Inc.: Thousand Oaks, CA, California, 2008; ISBN 9781412918084.

41. Fantini, E. Picturing Waters: A Review of Photovoice and Similar Participatory Visual Research on Water Governance. Wiley Interdiscip. Rev. Water 2017, 4, e1226. [CrossRef]

42. Maclean, K.; Woodward, E. Photovoice Evaluated: An Appropriate Visual Methodology for Aboriginal Water Resource Research. Geogr. Res. 2013, 51, 94-105. [CrossRef]

43. Harper, D. Talking about pictures: A case for photo elicitation. Vis. Stud. 2002, 17, 13-26. [CrossRef]

44. Archer, D.R.; Fowler, H.J. Spatial and Temporal Variations in Precipitation in the Upper Indus Basin, Global Teleconnections and Hydrological Implications. Hydrol. Earth Syst. Sci. 2004, 8, 47-61. [CrossRef]

45. Nüsser, M.; Schmidt, S.; Dame, J. Irrigation and Development in the Upper Indus Basin: Characteristics and Recent Changes of a Socio-hydrological System in Central Ladakh, India. Mt. Res. Dev. 2012, 32, 51-61. [CrossRef]

46. Dhiman, S.C. Rejuvenation of Aquifers. In Water Governance: Challenges and Prospects; Singh, A., Saha, D., Tyagi, A.C., Eds.; Springer: Singapore, 2019; pp. 187-204, ISBN 978-981-13-2700-1. 
47. Nüsser, M.; Dame, J.; Kraus, B.; Baghel, R.; Schmidt, S. Socio-hydrology of “Artificial Glaciers” in Ladakh, India: Assessing Adaptive Strategies in a Changing Cryosphere. Reg. Environ. Chang. 2019, 19, 1327-1337. [CrossRef]

48. Hock, R.; Rasul, G.; Adler, C.; Cáceres, B.; Gruber, S.; Hirabayashi, Y.; Jackson, M.; Kääb, A.; Kang, S.; Kutuzov, S.; et al. High Mountain Areas. In Special Report on the Ocean and Cryosphere in a Changing Climate; Pörtner, H.-O., Roberts, D.C., Masson-Delmotte, V., Zhai, P., Tignor, M., Poloczanska, E., Mintenbeck, K., Alegría, A., Nicolai, M., Okem, A., Eds.; IPCC: Geneva Switzerland, 2019; pp. 131-202.

49. Morup, T.; Chodon, R. The Old Town Leh, Ladakh. Available online: https://www.sahapedia.org/the-oldtown-leh-ladakh-0 (accessed on 3 April 2020).

50. Dame, J.; Nüsser, M. Development Perspectives in Ladakh, India. Geogr. Rundsch. Int. Ed. 2008, 4, $20-27$.

51. Gagné, K. Building a Mountain Fortress for India: Sympathy, Imagination and the Reconfiguration of Ladakh into a Border Area. South Asia J. South Asian Stud. 2017, 40, 222-238. [CrossRef]

52. Baghel, R.; Nüsser, M. Securing the Heights: The Vertical Dimension of the Siachen Conflict Between India and Pakistan in the Eastern Karakoram. Political Geogr. 2015, 48, 24-36. [CrossRef]

53. Tourism Department. Month Wise Tourist Arrival Statement for the Year 2018; Unpublished; Tourism Department: Leh, Ladakh, 2019.

54. Tetra Tech. Detailed Project Report for Sewerage System of Leh Town; Unpublished; 2009.

55. Gondhalekar, D.; Akhtar, A. Down the Drain or Back to the Roots? Political Ecology of the Water-Energy-Food Nexus Visualized Using GIS in Leh Town, Ladakh, India. In Projections 11 - Global Ecologies: Politics, Planning, and Design; Goh, K., Chu, E., Eds.; MIT Department of Urban Studies and Planning: Cambridge, MA, USA, 2015; pp. 77-98.

56. Ladakh Autonomous Hill Development Council (LAHDC). In Ladakh 2025 Vision Document; Leh, Ladakh, 2005. Available online: https:/cdn.s3waas.gov.in/s3291597a100aadd814d197af4f4bab3a7/uploads/2018/06/ 2018061732.pdf (accessed on 18 December 2019).

57. Kooy, M. Developing Informality: The Production of Jakarta's Urban Waterscape. Water Altern. 2014, 7, 35-53.

58. Kaika, M. City of Flows. Modernity, Nature, and the City; Routledge: New York, NY, USA; Abingdon, UK, 2005; ISBN 0-415-94715-4.

59. Gandy, M. Rethinking Urban Metabolism: Water, Space and the Modern City. City 2004, 8, 363-379. [CrossRef]

60. Schwaller, C. Assessment of the Impact of On-site Sanitation Systems on Groundwater Quality in Leh Town, India. Master Thesis, Technical University of Munich, Munich, Germany, 2018.

61. Ternes, B. Groundwater Citizenship and Water Supply Awareness: Investigating Water-Related Infrastructure and Well Ownership. Rural Sociol. 2018, 83, 347-375. [CrossRef]

62. In PM Narendra Modi's Speech, a Big Push to Domestic Tourism. Hindustan Times [Online]. 16 August 2019. Available online: https:/www.hindustantimes.com/india-news/in-modi-speech-a-big-push-to-domestictourism/story-0wfJuK0JsjX3fDXwXo05vM.html (accessed on 16 August 2019).

63. Scott, C.A.; Zhang, F.; Mukherji, A.; Immerzeel, W.; Mustafa, D.; Bharati, L. Water in the Hindu Kush Himalaya. In The Hindu Kush Himalaya Assessment: Mountains, Climate Change, Sustainability and People; Wester, P., Mishra, A., Mukherji, A., Shrestha, A.B., Eds.; Springer: Cham, Germany, 2019; pp. 257-299, ISBN 978-3-319-92287-4.

64. Rao, N.; Suresh, K.T. Domestic Tourism in India. In The Native Tourist: Mass Tourism Within Developing Countries; Ghimire, K.B., Ed.; Earthscan: London, UK; New York, NY, USA, 2001; ISBN 9781853838040.

65. Perlik, M. The Spatial and Economic Transformation of Mountain Regions. Landscapes as Commodities; Routledge: Abingdon, UK; New York, NY, USA, 2019; ISBN 9781138784086.

66. Singh, S.; Tanvir Hassan, S.M.; Hassan, M.; Bharti, N. Urbanisation and Water Insecurity in the Hindu Kush Himalaya: Insights from Bangladesh, India, Nepal and Pakistan. Water Policy 2019, 26, 179. [CrossRef]

(C) 2020 by the authors. Licensee MDPI, Basel, Switzerland. This article is an open access article distributed under the terms and conditions of the Creative Commons Attribution (CC BY) license (http://creativecommons.org/licenses/by/4.0/). 